\title{
Lymphoplasmacyte-rich meningioma involving the whole intracranial dura mater
}

Xiang Yang, MD,* Jun Le, MD,* Xin Hu, MD, Yuekang Zhang, MD, and Jiagang Liu, MD

Neurology ${ }^{\circledR}$ 2018;90:934-935. doi:10.1212/WNL.0000000000005532
Correspondence

Dr. Liu

yangxiangcool2017@

163.com

Figure MRI, surgery, tumor, and pathology of the lymphoplasmacyte-rich meningioma
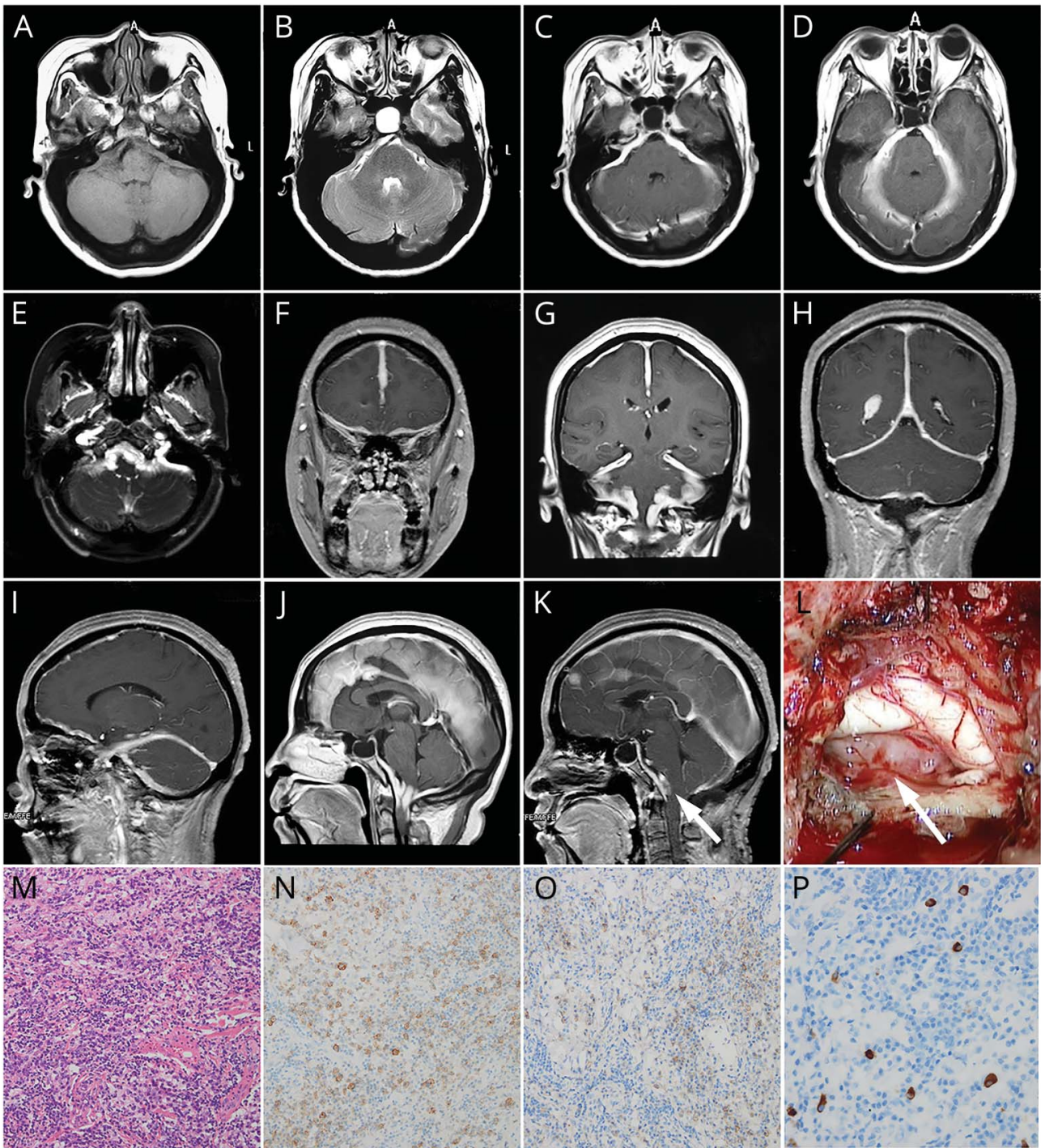
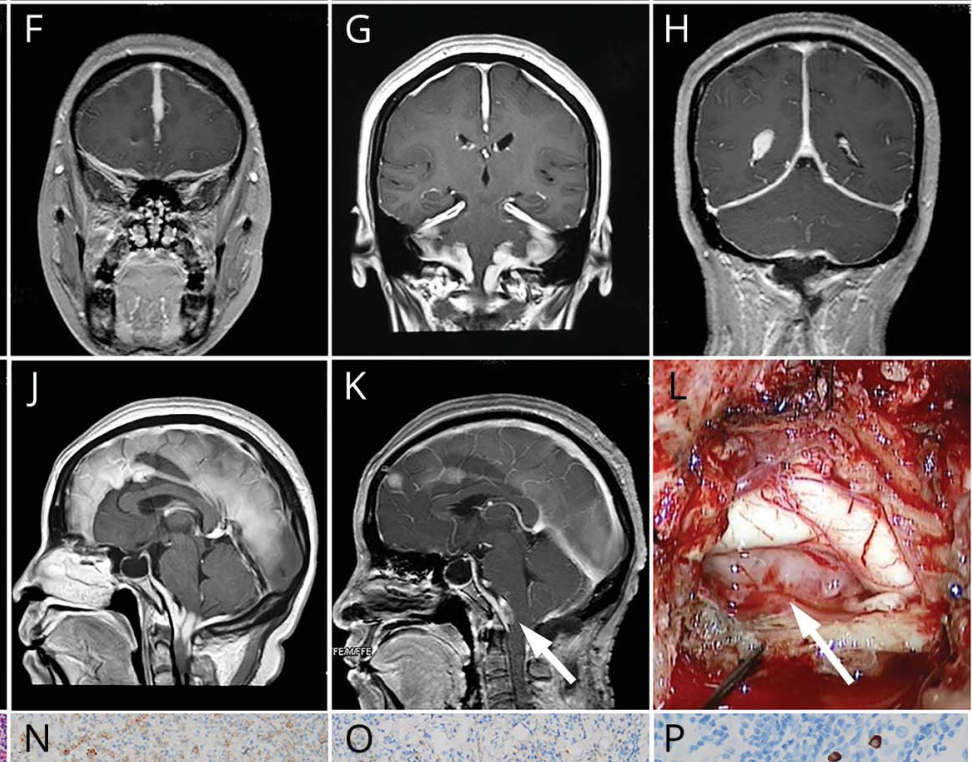

0

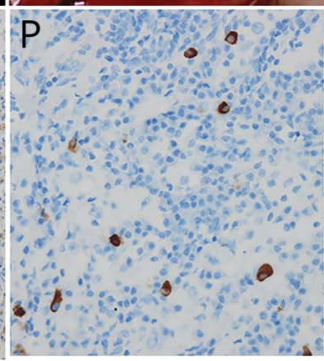

MRI: T1-weighted (A), T2-weighted (B), and gadolinium contrast (C) of bilateral cerebellopontine angle (CPA); bilateral cerebellar tentorium (D); bilateral foramen magnum (E); falx cerebri and bilateral frontal base (F); falx cerebri, bilateral parietal lobe, bilateral cerebellar tentorium, and bilateral CPA (G); falx cerebri, bilateral cerebellar tentorium, and the right trigone area of the lateral ventricle $(\mathrm{H})$; frontal base, cerebellar tentorium, and CPA (I); clival region and foramen magnum (J); postsurgery (white arrow) (K); surgery (white arrow) (L); hematoxylin \& eosin (magnification, $\times 200)(\mathrm{M})$; immunohistology positive: epithelial membrane antigen (magnification, $\times 200)(N)$, CD138 (magnification, $\times 200)(O)$, immunoglobulin G4 (magnification, $\times 400)(P)$.

A 47-year-old woman presented with a 6-month history of occipital-cervical region pain, numbness of both upper limbs, and progressive bilateral hearing loss. Enhanced MRI revealed a lesion involving the intracranial dura mater and the right trigone area of the lateral ventricle

*These authors contributed equally to this work.

From the Department of Neurosurgery (X.Y., X.H., Y.Z., J. Liu), West China Hospital, Sichuan University Chengdu; and Department of Neurosurgery (J. Le), Yingtan People's Hospital of Jiangxi, P.R. China.

Go to Neurology.org/N for full disclosures. Funding information and disclosures deemed relevant by the authors, if any, are provided at the end of the article. 
(figure, A-J). Surgery to relieve the main symptoms was performed through a posterior midline approach (figure, $\mathrm{K}$ and $\mathrm{L}$ ). Pathology suggested the diagnosis of lymphoplasmacyte-rich meningioma (figure, M-P). Lymphoplasmacyte-rich meningioma is a rare variant of meningioma and is categorized as a WHO grade I tumor and approximately 60 cases have been reported, ${ }^{1}$ but involvement of the entire intracranial dura mater is unusual. It is characterized by dense lymphoplasmacytic infiltration and usually treated with surgical resection ${ }^{1}$; however, total resection could not be achieved in our case. The patient received radiotherapy and postsurgery MRI at 3 months but demonstrated no progress.

\section{Author contributions}

Xiang Yang: study design, data collection and analysis, drafting the manuscript, revising the manuscript. Jun Le: data collection, drafting the manuscript, revising the manuscript. Xin $\mathrm{Hu}$ : acquisition of data, analysis and interpretation of data. Yuekang Zhang: study concept and design. Jiagang Liu: in charge of surgery, clinical care and investigative workup of the patient, study concept and design, and revision of manuscript.

\section{Study funding}

No targeted funding reported.

\section{Disclosure}

The authors report no disclosures relevant to the manuscript. Go to Neurology.org/N for full disclosures.

\section{Reference}

1. Cha YJ, Lee SK, Chang JH, Kim SH. Report of a rare case of atypical lymphoplasmacyte-rich meningioma in the tentorium mimicking idiopathic hypertrophic pachymeningitis. Brain Tumor Pathol 2016;33:216-221.

\section{Subspecialty Alerts by E-mail!}

Customize your online journal experience by signing up for e-mail alerts related to your subspecialty or area of interest. Access this free service by clicking on the "My Alerts" link on the home page. An extensive list of subspecialties, methods, and study design choices will be available for you to choose from-allowing you priority alerts to cutting-edge research in your field!

\section{AAN Leadership Program Opportunities}

Applications are open for four one-of-a-kind AAN Leadership Program opportunities. Apply by June 4 at AAN.com/view/Lead.

\section{- Emerging Leaders}

Designed to identify, engage, and mentor early career members who are committed to professional, community, and society leadership.

- Transforming Leaders

Designed to identify and develop talent among experienced members.

- Practice Leadership

Designed to develop and hone the kind of unique leadership skills critical for today's practicing neurologist to succeed and flourish.

- Women Leading in Neurology

Designed to identify, engage, and mentor mid-career female member neurologists who are committed to professional, community, and society leadership. 


\section{Neurology}

Lymphoplasmacyte-rich meningioma involving the whole intracranial dura mater Xiang Yang, Jun Le, Xin Hu, et al.

Neurology 2018;90;934-935

DOI 10.1212/WNL.0000000000005532

This information is current as of May 14, 2018

\section{Updated Information \&} Services

References

Citations

Subspecialty Collections

Permissions \& Licensing

Reprints including high resolution figures, can be found at: http://n.neurology.org/content/90/20/934.full

This article cites 1 articles, 0 of which you can access for free at: http://n.neurology.org/content/90/20/934.full\#ref-list-1

This article has been cited by 2 HighWire-hosted articles: http://n.neurology.org/content/90/20/934.full\#\#otherarticles

This article, along with others on similar topics, appears in the following collection(s):

MRI

http://n.neurology.org/cgi/collection/mri

Primary brain tumor

http://n.neurology.org/cgi/collection/primary_brain_tumor

Information about reproducing this article in parts (figures,tables) or in its entirety can be found online at:

http://www.neurology.org/about/about_the_journal\#permissions

Information about ordering reprints can be found online:

http://n.neurology.org/subscribers/advertise

Neurology ${ }^{\circledR}$ is the official journal of the American Academy of Neurology. Published continuously since 1951, it is now a weekly with 48 issues per year. Copyright () 2018 American Academy of Neurology. All rights reserved. Print ISSN: 0028-3878. Online ISSN: 1526-632X.

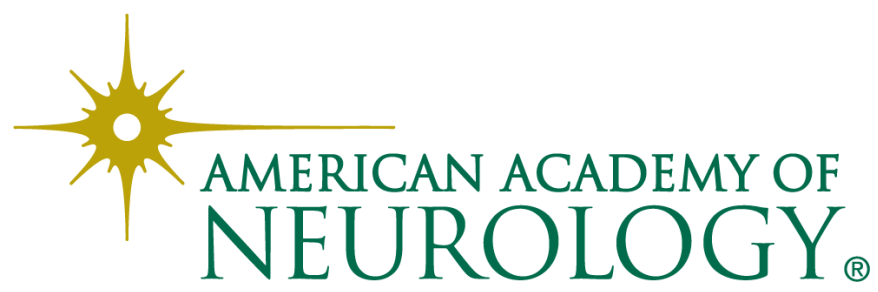

